\section{Homicídio sexual: relato de caso de perícia psiquiátrica forense}

\section{Sexual homicide: case report of a forensic psychiatric evaluation}

Caro Editor,

O homicídio sexual é o assassinato intencional de um indivíduo, durante o qual há comportamento sexual realizado pelo perpetrador. Trata-se de evento raro, que atrai a atenção psiquiátrica, tanto nos casos únicos, quanto naqueles em série. Estima-se que representem menos de 1\% dos homicídios anuais, legalmente conhecidos, nos Estados Unidos ${ }^{1}$. Estatísticas brasileiras informam que os delitos sexuais representam 18\% das perícias de Responsabilidade Penal realizadas no Instituto Psiquiátrico Forense (IPF) ${ }^{2}$. Já no Estado de São Paulo, 5\% dos homens presos cumprem pena em virtude de crime sexual ${ }^{3}$.

A maioria destes delitos é cometida por homens menores de 30 $\operatorname{anos}^{1}$. As vítimas são, preferencialmente, mulheres desconhecidas ou parceiras casuais, da mesma raça do agressor. Os homicidas sexuais, habitualmente, não são psicóticos e os diagnósticos do eixo I mais encontrados, baseados no DSM-IV, são sadismo sexual e uso de álcool e drogas ${ }^{1}$. O eixo II, por sua vez, é preenchido pelos transtornos de personalidade antissocial e narcisista ${ }^{4}$.

A cena do crime nos homicídios sexuais pode ser organizada ou desorganizada, segundo uma classificação desenvolvida pelo Federal Bureau of Intelligence (FBI $)^{1}$. O sadismo sexual é um elemento que emerge como prelúdio de homicídios sexuais em série e pode ser encontrado facilmente, nos tipos organizados.

Descrevemos o caso de um homem branco, de 29 anos, solteiro, com ensino fundamental incompleto, caminhoneiro, sem antecedentes criminais, encaminhado para avaliação de Responsabilidade Penal no IPF, pelos delitos de homicídio qualificado, estupro e atentado violento ao pudor. $\mathrm{O}$ acusado abordou a vítima, jovem de idade semelhante, branca, fisioterapeuta, em rodovia, fazendo-a sair de seu veículo. Agarrou-a, levou-a para um barranco, imobilizou-a usando uma corda, torturou-a e praticou atos sexuais diversos. Ao final, desferiu quinze golpes de facão em seu pescoço, causando-lhe a morte. Abandonou o local do crime, trocou suas vestes e conduziu seu veículo para a entrega das mercadorias em outro Estado, onde se desfez da arma. Confessou ter praticado o homicídio, porém afirmou não se recordar dos fatos, pois sua consciência estaria alterada pelo uso de anfetaminas, que afirmava consumir durante as viagens. A história narrada estava repleta de mentiras, não revelava indícios de transtornos mentais pelo uso de substâncias, psicose ou retardo mental. Crueldade, ausência de remorso, falta de empatia, conduta manipuladora e frieza emocional foram aferidas no psicodiagnóstico. Estes sintomas, associados ao escore da Psychopathy Checklist Revised (22), levaram os peritos a concluir pela presença de traços antissociais de personalidade. $\mathrm{O}$ resultado da Historical, Clinical, Risk Management-20 (23) indicou importante risco de violência. As fantasias sádicas sexuais, embora não admitidas, tiveram sua concreta expressão por meio das imagens post mortem da vítima e das descrições do exame médico legal. A conclusão do laudo pericial indicou plena imputabilidade.

As características deste crime corroboram as pesquisas sobre o tema: trata-se de homicídio sexual com elementos organizados e desorganizados, executado por agressor jovem, sádico, portador de traços antissociais de personalidade, que selecionou vítima desconhecida, de mesma cor, negando parcialmente a violência sexual cometida e atribuindo a responsabilidade para um estado alterado de consciência, por intoxicação ${ }^{5}$.

Este caso fornece algumas características de um homicida sexual local, ressaltando as dificuldades existentes para avaliar a motivação deste tipo de delito, o que deve ser um marco de futuras pesquisas.

Alcina Juliana Soares Barros

Psiquiatria Forense, Universidade Federal de Ciências da Saúde de Porto Alegre (UFCSPA), Porto Alegre, RS, Brasil

Lisieux Elaine de Borba Telles Instituto Psiquiátrico Forense Maurício Cardoso, Porto Alegre, RS, Brasil

Psiquiatria Forense, Universidade Federal de Ciências da Saúde de Porto Alegre (UFCSPA), Porto Alegre, RS, Brasil

Pedro Henrique Iserhard Zoratto, Marília Alves da Luz Hentschel, Larissa Melgarejo Santarém Instituto Psiquiátrico Forense Maurício Cardoso, Porto Alegre, RS, Brasil 
Financiamento e conflito de interesses

\begin{tabular}{|c|c|c|c|c|c|c|c|}
\hline $\begin{array}{l}\text { Membro do grupo } \\
\text { de autores }\end{array}$ & $\begin{array}{l}\text { Local de } \\
\text { trabalho }\end{array}$ & $\begin{array}{l}\text { Verba de } \\
\text { pesquisa }\end{array}$ & $\begin{array}{c}\text { Outro apoio à } \\
\text { pesquisa ou educação } \\
\text { médica continuada }^{2}\end{array}$ & $\begin{array}{l}\text { Honorários } \\
\text { de } \\
\text { palestrantes }\end{array}$ & $\begin{array}{l}\text { Participação } \\
\text { acionária }\end{array}$ & $\begin{array}{l}\text { Consultor/ } \\
\text { conselho } \\
\text { consultivo }\end{array}$ & Outro $^{3}$ \\
\hline $\begin{array}{l}\text { Alcina Juliana Soares } \\
\text { Barros }\end{array}$ & UFCSPA & - & - & - & - & - & - \\
\hline $\begin{array}{l}\text { Lisieux Elaine de } \\
\text { Borba Telles }\end{array}$ & $\begin{array}{l}\text { IPFMC } \\
\text { UFCSPA }\end{array}$ & - & - & - & - & - & - \\
\hline $\begin{array}{l}\text { Pedro Henrique } \\
\text { Iserhard Zoratto }\end{array}$ & IPFMC & - & - & - & - & - & - \\
\hline $\begin{array}{l}\text { Marília Alves da Luz } \\
\text { Hentschel }\end{array}$ & IPFMC & - & - & - & - & - & - \\
\hline $\begin{array}{l}\text { Larissa Melgarejo } \\
\text { Santarém }\end{array}$ & IPFMC & - & - & - & - & - & - \\
\hline \multicolumn{8}{|l|}{$\begin{array}{l}\text { * Modesto } \\
* * \text { Significativa }\end{array}$} \\
\hline
\end{tabular}

Referências

1. Meloy JR. The nature and dynamics of sexual homicide: an integrative review. Aggression violent behavior. 2000;5(1):1-22.

2. Telles LEB. Perícias de responsabilidade penal realizadas no Instituto Psiquiátrico Forense. Multijuris: Primeiro Grau em Ação. 2007;2(3):44-9.

3. Baltieri DA, Andrade AG. Comparing serial and nonserial sexual offenders: alcohol and street drug consumption, impulsiveness and history of sexual abuse. Rev Bras Psiquiatr. 2008;30(1):25-31.

\section{Mania switch induced by amantadine in bipolar disorder: report of three cases}

\section{Virada maníaca induzida pela amantadina no transtorno bipolar: relato de três casos}

Dear Editor,

Bipolar disorder (BD) is often a severe and chronic disease. It has been shown that subjects with $\mathrm{BD}$ present cognitive impairment during the acute phase of the disease and remission, which seems to worsen with the recurrence of episodes. Available treatments are successful in reducing symptoms in acute mania and depression. However, their effects in the functional recovery of patients are minor. As previously shown in schizophrenia $(\mathrm{SZ}){ }^{1} \mathrm{BD}$ is associated with cognitive impairment (as seen in psychometric tests), neuroanatomical changes (evidenced in imaging studies), and neurotransmission dysregulation, such as in the case of glutamate. ${ }^{2}$ It has also been demonstrated that serum levels of brain-derived neurotrophic factor (BDNF), which
4. Stone MH. Sexual sadism: a portrait of evil. J Am Acad Psychoanal Dyn Psychiatry. 2010;38(1):133-57.

5. Folino JO. Estudios Argentino sobre homicidas. In: Folino JO, EscobarCórdoba F, editors. Estudios sobre homicidios: perspectivas forenses, clinica y epidemiológica. La Plata: Libreria Editora Platense; 2009. p.65-152.

is a protein related to neuroplasticity, are decreased during $\mathrm{BD}$ mood episodes. ${ }^{3}$

The adjunctive use of amantadine, a memantine derivative, has shown to be conducive to cognitive improvement in subjects with $\mathrm{SZ}^{4}$ and BD. ${ }^{5}$ This is so because amantadine has several properties: a) it increases the monoaminergic tonus via dopamine, norepinephrine, and serotonin in the amygdala and hippocampus b) has an antidepressant activity c) directly modulates glutamate as a partial agonist of $\mathrm{N}$-methyl-D-aspartate (NMDA) receptors, and d) contributes to BDNF increase and stabilizes the neuronal membrane. Amantadine use in patients with $\mathrm{BD}$ has not been associated with mood swings. ${ }^{5}$

We evaluated the use of amantadine adjunctive therapy for improving the cognitive impairment of three euthymic DSM-IV BD type I subjects who presented with a standard clinical pattern of cognitive and behavioral impairment or who were unable to live autonomously. ${ }^{3}$ Subjects gave informed consent for the experimental use of amantadine administered at increased doses of up to $400 \mathrm{mg}$ over a period of 8 weeks. Patients were evaluated by means of a psychiatric interview and their clinical response was assessed using the Young Mania Rating Scale (YMRS) and the 17-item Hamilton Depression Scale (HAMD). The three cases are illustrated in Table 1. All subjects had mania switches and the consequent worsening of cognitive impairment. Subject 3 presented a slightly different evolution, since it tolerated $200 \mathrm{mg}$ 